Apidologie, 1985, 16 (1), 47-56

\title{
ESTIMATING HERITABILITIES OF WORKER CHARACTERS : A NEW APPROACH USING LAYING WORKERS OF THE CAPE HONEYBEE (APIS MELLIFERA CAPENSIS ESCH.)
}

\author{
Robin F.A. MORITZ \\ Institut fïr Bienenkunde (Polytechn. Ges.), J.W. Goethe Universität Frankfurt/M. \\ Karl-von-Frisch-Weg 2, D 6370 Oberursel/Ts \\ Andreas KLEPSCH \\ Hessische Landesanstalt für Leistungsprüfungen in der Tierzucht \\ Abteilung fïr Bienenzucht, Erlenstr. 9, D 3575 Kirchhain 1
}

\section{SUMMARY}

Heritabilities $\left(h^{\prime \prime}\right)$ of worker characters in honeybees are estimated with laying workers of Apis mellifera capensis. Estimates of $\mathbf{h}^{2}$ of several morphological characters by parent-offspring regression (laying workers) and sib analysis (classical technique) result in similar values. Laying workers may become an important tool for behaviour genetical experiments in both, selection of special behavioural traits of individual worker bees and estimation of the most basic quantitative genetic parameters in the honeybee.

\section{INTRODUCTION}

Heritabilities $\left(\mathrm{h}^{2}\right)$ of characters of workers in honeybees (Apis mellifera $\mathbf{L}$.) are important parameters in breeding programs. The heritability in the broader sense $\left(\mathrm{h}^{2}{ }_{\mathrm{ils}}\right)$ of a certain character is given by the ratio of genetic variation (variance due to additive $\left(\mathrm{S}_{\mathrm{A}}^{2}\right)$ and non-additive $\left(\mathrm{S}_{\mathrm{D}}^{2}\right)$ effects) to total phenotypic variation $\left(\mathrm{S}^{2}{ }^{2}\right)$.

$$
\mathrm{h}_{\mathrm{jl \textrm {s }}}=\frac{\text { genetic variance }}{\text { phenotypic variance }}=\frac{\mathrm{S}_{{ }_{\mathrm{A}}}+\mathrm{S}^{2}{ }_{\mathrm{D}}}{\mathrm{S}^{2}{ }_{\mathrm{P}}}
$$

In applied selection programs especially the heritability in the narrow sense 
$\left(\mathrm{h}^{2}{ }_{\mathrm{ins}}\right)$ is of great importance. $\mathrm{h}^{2}{ }_{\mathrm{ins}}$ estimates the the ratio of additive genetic variance $\left(\mathrm{S}^{2}{ }_{A}\right)$ to $\mathrm{S}^{2}{ }_{1}$ and allows one to predict the response to selection.

$$
\mathrm{h}^{2}{ }_{\mathrm{i} 1 \mathrm{~S}}=\mathrm{S}^{2}{ }_{\mathrm{N}} / \mathrm{S}^{2}{ }_{\mathrm{P}}{ }^{2}
$$

$\mathbf{h}^{2}$ for worker characters are usually estimated by sib analysis (PIrcurver et al., 1962 ; RindERIR, 1977 ; OLdRoyd \& MORAn, 1983). h can be casily estimated, by either determining the intraclass correlation, which gives good estimates of $h^{2}$ in natural mating, or a nested analysis of variance with half sib and full sib families, which can only be performed with artificial insemination. A parent offspring regression analysis, though generally a good predictor for $h^{2}$ (FALcoNer, 1981), is in most cases inappropriate for estimating h" of worker characters, because of the differences in physiology and behaviour between the castes and sexes (eg. foraging behaviour is not present in both reproductives, queens and drones). In other cases, when there are no obvious differences between the castes, the regression method may be feasable (eg. disease resistance) (RINDERER and Rotenbuhler, 1969). However RinderIR (1977) points out that an estimate of the heritability in a queen - daughter-queen structure may well be different from a queen - daughter-worker estimate. There are no problems in regression estimates of $h^{2}$ as long as within caste analysis (queen-queen ; drone-drone ; workerworker) are performed. Hence using laying workers which produce female worker offspring would solve the problem of applying regression analysis to heritability estimates of worker characters.

The Cape honeybee (Apis mellifera capensis) gives an unique opportunity to estimate $\mathrm{h}^{2}$ of worker characters by regression analysis. Laying workers of the Cape honeybee are able to produce female offspring by automictic parthenogenesis (OnIONS, 1912 ; Anderson, 1963). Verma and RutTner (1983) showed that there is a central fusion of the post meiotic egg and one polar body. Therefore there is only occasionally genetic recombination in case of cross over during the first meiotic division. Estimating $\mathrm{h}^{2}$ with both sib analysis and parent offspring regression should reveal whether similar results (and thus reliable estimates of $\mathrm{h}^{2}$ ) can be obtained by regression analysis with laying workers.

\section{MATERIAL AND METHODS}

Sib analysis. A nested sib analysis according to RinDERER (1977) was performed with Cape honeybees (Apis mellifera capensis). Five unrelated sire queens produced the drones which were mated to four unrelated queens (dams) each. Samples of 32 drones of each sire queen provided semen and each dam was inseminated at the age of 7 days after emergence with a semen load of $8 \mu \mathrm{l}$ from 8 drones of a single sire queen according to the method of RuTtNer (1976). Hence «full sib families» (common sire and common dam) and «half sib families» (common sire but 
different dam) could be distinguished (Fig. 1). Within the full sibs there are groups of super sisters (common drone) and full sisters (different drone but common sire) which cannot be detected unless marker genes are used. As the dams were inseminated with semen of eight drones and have an unequal distribution of the semen in the spermatheca, an estimate of the coefficient of relationship « $r$ » (WRIGHT, 1921) between the workers of one colony becomes difficult. Semen of some drones may be genetically more effective than others which leads to complications in estimating. the exact relationship of the workers in the full sib groups. An approximation of the worker relatedness for inseminations of queens with eight drones and non-homogenous semen distribution is given by MORITZ (1984). The coefficient of relationship ( $r$ ) between the workers of one colony (common sire, common dam) can be estimated by $r=0.543$. This is larger than for random distribution of the semen.

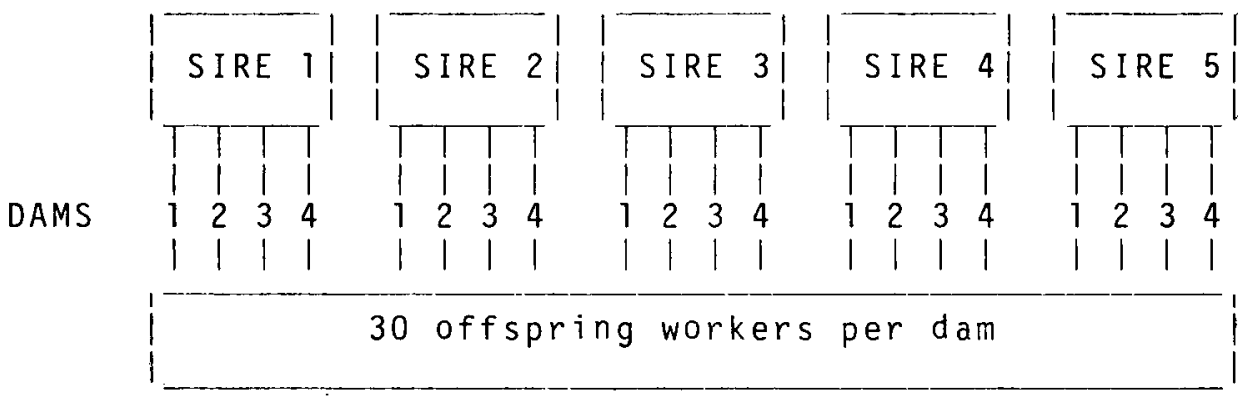

Fic. 1. - Nested breeding scheme to produce full and half sib families

Each dam is inseminated with semen $(8 \mu 1)$ of a set of eight drones produced by the according sire queen.

The queens were kept in mating nuclei (2,500 bees). After a sufficient number of brood cells were sealed $(n=50)$ the combs were placed into an incubator $\left(35^{\circ} \mathrm{C}, 60 \% \mathrm{RH}\right)$ to standardize environmental effects and let the brood emerge.

Parent offspring regression. Freshly emerged workers of $\mathcal{A} . \boldsymbol{m}$. capensis were individually marked on the thorax and the right fore wing was clipped. Five workers each were introduced into queenless colonies (2,500 bees) of A.m. carnica, expecting at least one capensis worker to be accepted, as it is sometimes difficult to introduce foreign worker bees into a colony. Seven days after introduction the combs were inspected for eggs laid by the capensis workers (carnica workers start oviposition not before 30 days after queenloss [RUTTNER and Hesse, 1981]). In several cases more than one capensis worker still was in the colony. The one with the largest abdomen was left (assuming to be the most fertile worker), whereas the others were removed from the colony. This procedure assured that those bees which emerged after 22 days all had one common mother. The brood combs were removed after this time from the colony, to let the brood emerge in the incubator $\left(35^{\circ} \mathrm{C}, 60 \% \mathrm{RH}\right)$. Offspring of 20 laying workers was tested.

Wing preparation. The right fore wings of 30 offspring workers per colony were clipped, and embedded in a polyvinyl alcohol mixture $(204 \mathrm{ml} \mathrm{H.O} ; 36 \mathrm{~g}$ polyvinyl alcohol ; $40 \mathrm{~g} \mathrm{lactic}$ acid; $40 \mathrm{~g}$ phenole, continuously stirred at $80^{\circ} \mathrm{C}$ ) on a glass slide. The wing preparations were dried at $45^{\circ} \mathrm{C}(48 \mathrm{~h})$ for documentation. Morphological characters of the wing veination of A.m. capensis workers (5 angles, three lengths, Fig. 2) were measured on a profile projector (50 x; Leitz) according to the method of RUTTNER et al. (1978). 


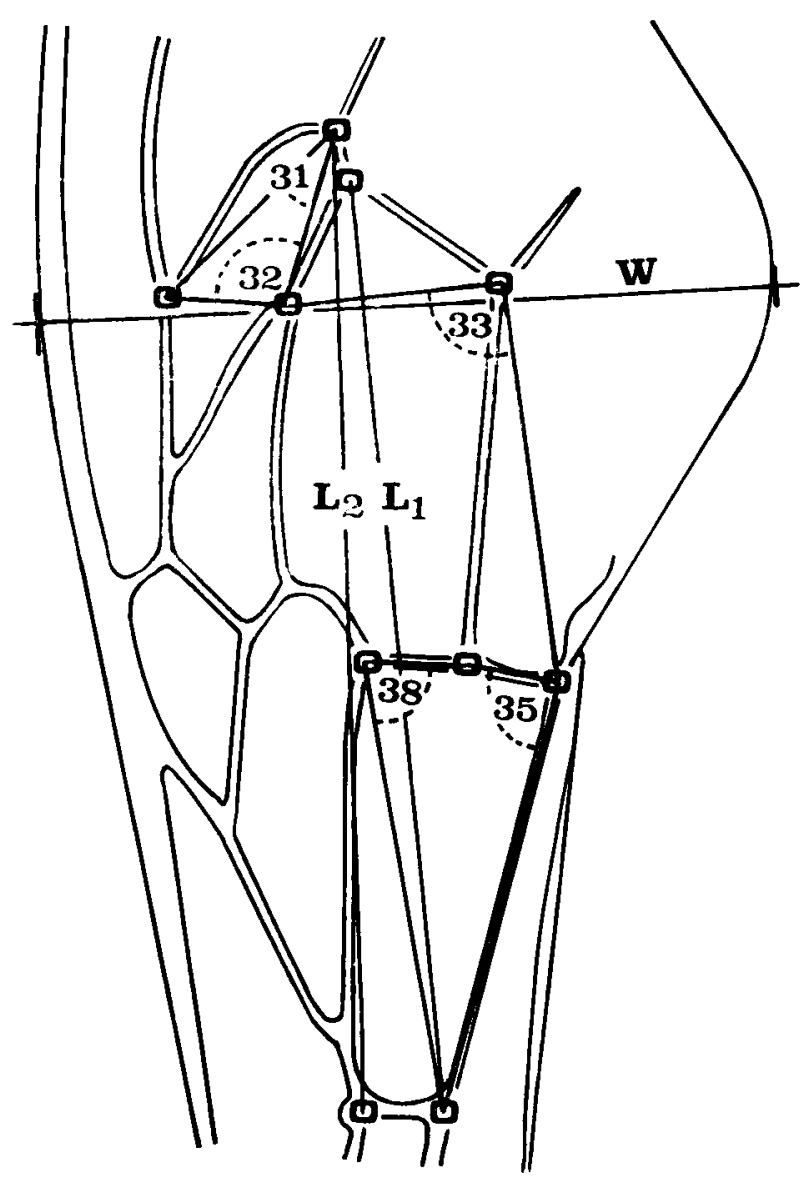

FIG. 2. - Diagram of the right fore wing of a worker bee, showing the measured morphological characters

$\mathrm{L} 1$ and $\mathrm{L} 2=$ lengths, $\mathrm{W}=$ width, $31-38=$ angles in the wing veination pattern.

\section{RESULTS}

The structure of the sib analysis allows one to estimate additive and dominance variance. The relationship of the half sib workers (common sire only) is $r=0.25$, as different drones of each sire queen were used for insemination. As a result the sire variance component estimates

$$
\mathrm{COV}_{\mathrm{IIS}}=.25 \mathrm{~S}^{2}{ }_{\mathrm{A}}
$$


As the average relationship between workers of one colony (full sibs \& super sibs, eight drones per mating), is $r=.543$, the sum of dam variance component and sire component estimates

$$
\operatorname{COV}_{\mathrm{rs}}=.543 \mathrm{~S}_{\mathrm{A}}^{2}+.27 \mathrm{~S}^{2}{ }_{\mathrm{D}}
$$

$\mathrm{COV}_{\mathrm{Fs}}=$ Covariance of workers within one colony (full sibs \& super sibs)

$\mathrm{COV}_{\mathrm{IS}}=$ Covariance of half sibs

the heritability is estimated in case of full sibs by

$$
\mathrm{h}^{2}{ }_{\mathrm{ins}}=\left[(1 / .543) \mathrm{COV}_{\mathrm{Fs}}\right] / \mathrm{S}^{2}{ }{ }^{\prime}
$$

and in case of half sibs by

$$
\mathrm{h}^{2}{ }_{\mathrm{ins}}=4 \mathrm{COV}_{\mathrm{HIS}} / \mathrm{S}^{2} \mathrm{i}^{\prime}
$$

Table 1 shows the estimates of the respective variances, covariances and $\mathrm{h}^{2}$ of the tested characters. The values of $h^{2}$ larger than one and the negative estimates

\begin{tabular}{|c|c|c|c|c|c|c|c|c|}
\hline Character & Width & L1 & 12 & 31 & 32 & 33 & 35 & 38 \\
\hline $\mathrm{COV}_{\mathrm{HS}}$ & .098 &, 048 & .105 & 2.68 & 3.04 & 5.50 & .35 & 1.14 \\
\hline $\mathrm{COV}_{\mathrm{FS}}$ & 140 & .176 & .211 & 5.68 & 23.72 & 9.10 & 1.38 & 3.92 \\
\hline $\mathrm{S}^{2}{ }_{\mathrm{A}}$ & .390 & .192 & .420 & 10.72 & 12.17 & 20.20 & 1.40 & 4.57 \\
\hline$S_{D}^{*}$ & -.24 & .245 & -.05 & -.46 & 58.40 & -6.4 & 2.11 & 4.90 \\
\hline $\mathrm{S}_{\mathrm{I}}{ }^{\prime}$ & .244 & .322 & .368 & 10.04 & 46.86 & 17.08 & 8.62 & 11.54 \\
\hline$h^{y}$ (IIS) & 1.59 & .590 & 1.14 & 1.07 & .26 & 1.18 & .16 & .396 \\
\hline $\mathrm{h}^{\prime \prime}$ (FS) & 1.07 & 1.01 & 1.05 & 1.04 & .93 & .98 & .29 & .625 \\
\hline
\end{tabular}
of $\mathrm{S}^{2}{ }_{\mathrm{i}}$ may be due to the small sample size.

TABL. 1. - Results from the s:b analysis

The most important variances ( $\mathrm{A}=$ additive $; \mathrm{D}=$ dominance, $\mathbf{P}=$ phenotypic), covariances (HS $=$ half sibs; FS $=$ full sibs) and the estimates for $h^{2}$ (from half sib (HS) and from full sib (FS) analysis) are listed.

The parent-offspring regression analysis gives similar results for $\mathrm{h}^{2}$ estimates. The heritability (in broader sense) is estimated by the regression coefficient directly. The relationship between parthenogenetically produced workers to their mother is $\mathrm{r}=1$ (not regarding recombination by cross over). The covariance between parent and offspring can be calculated as follows according to MALECOT (1948).

$\Phi=$ average probability of gene in offspring transferred by female gamete identical by descent to mother gene

$=1$ 
$\Phi^{\prime}=$ average probability of gene in offspring transferred by male gamete identical by descent to father gene

$=1$

hence

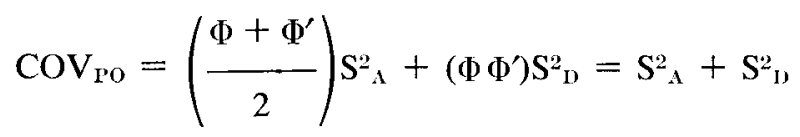

and

$$
\mathrm{h}^{2}=\mathrm{b}=\frac{\mathrm{COV}}{\mathrm{S}_{{ }_{1}{ }^{*}}}=\left(\mathrm{S}^{2}{ }_{\mathrm{A}}+\mathrm{S}^{2}{ }_{\mathrm{D}}\right) / \mathrm{S}_{{ }^{2}}^{2}
$$

$\mathrm{b}=$ regression coefficient

$\mathrm{S}_{\mathrm{P}}^{2}=$ total phenotypic variance

TABL. 2. - Estimates of $h^{2}$ from regression analysis $\left(h^{2}{ }_{\text {reg. }}\right)$ and sib analysis ( $h^{2}$ anova.

\begin{tabular}{|c|c|c|c|c|c|c|c|c|}
\hline Character & Width & $\mathrm{L} 1$ & L2 & 31 & 32 & 33 & 35 & 38 \\
\hline $\mathrm{h}_{\text {reg. }}^{2}$ & $.93 \pm .04$ & $.56 \pm .06$ & $.91 \pm .05$ & $.85 \pm .1$ & $.54 \pm .09$ & $.75 \pm .08$ & $.20 \pm .05$ & $.47 \pm .08$ \\
\hline $\mathrm{h}^{2}$ (anova) & $1.3 \pm .13$ & $.80 \pm .11$ & $1.1 \pm .13$ & $1.1 \pm .12$ & $.59 \pm .1$ & $1.1 \pm .11$ & $.22 \pm .07$ & $.51 \pm .10$ \\
\hline
\end{tabular}
average from $h_{(H S)}^{*}$ and $\left.h_{(F S)}^{*}\right)$

The Spcarman's rank correlation test reveals a significant correlation $\left(r_{s}=0.96 ; p \leftrightharpoons 0.001\right)$ between both methods.

Thus the total dominance variance is included in the estimate of $\mathrm{h}^{2}$ which may bias the estimate of $\mathrm{h}^{2}$ in the narrow sense in case of large dominance effects. Table 2 shows the estimated values of $\mathrm{h}^{2}$ in broader sense for the according characters when calculated by regression analysis. In general lower heritabilities than in the sib analysis are obtained. There is a significant correlation (Spearman's rank test $r_{s}=.96 ; p \leqslant 0.001$ ) between the estimates of $h^{2}$ from the sib analysis and from the parent offspring regression.

\section{DISCUSSION}

The estimates of $\mathrm{h}^{2}{ }_{\text {ibs }}$ by parent offspring regression correlate quite well $\left(\mathrm{r}_{\mathrm{s}}=.96 ; \mathrm{p} \leqslant .001\right)$ with the values of $\mathrm{h}^{2}{ }_{\text {ins }}$ obtained from the sib analysis. This shows that non-additive effects in this study seem to play a minor role. In this 
case the use of laying workers proves to be a reliable technique for estimating quantitative genetic parameters. The smaller values of $h=$ in the regression analysis may either result from an overestimation of relationship (effects of crossing over could not be estimated in this system), a more acceurate estimate or seasonal effects. In the sib analysis all tested workers were reared simultaneously. In the regression analysis the parental generation is reared in the early season (May) whereas the offspring were produced in midseason (July). Such seasonal effects are known to bias the heritability (eg. JOHANSSON and KORKMAN, 1950). In general the estimates of $\mathrm{h}^{2}$ for the tested morphological characters are high in the population of $A . m$. capensis tested in our study. Other authors obtained values for the intraclass correlation of the number of wing hamuli in other bee races ranging from .19 to .29 (Roberts, 1961; LeE, 1974). Oldroyd \& Moran (1983) estimated $\mathrm{h}^{2}=.68$ for this character which is similar to our data of the wing morphology. Goncalves (1972) obtained a regression coefficient of .95 for the number of hamuli in a parent offspring analysis. However he selected across castes, which results in difficulties when estimating the heritability. Nevertheless morphological characters seem to have higher heritabilities than physiological characters of honeybee colonies which range from .2 to .37 (PirCHNER et al., 1962 ; Soller \& Bar Cohen, 1968 ; Vesely \& Siller, 1963 ; Kriwzow, 1976). Also heritabilities of learning behaviour of individual worker bees range within these limits (BrANDIs \& Moritz, 1983). Similar phenomena are well known for other livestock, where physiological characters in most cases have lower estimates of $\mathrm{h}^{2}$ than morphological (eg. FAlCONER, 1981).

The advantage of using laying capensis workers for $\mathrm{h}^{2}$ estimates is the high accuracy of the determination of genetic variation. As the offspring of laying workers are closely related, the error of the estimate is very small compared to other methods. Specially the estimate of $h^{2}$ in narrow sense in the present paper, using the sire variance only, shows the effects of a low precision of the estimate. This also affects the estimate of $\mathrm{S}_{1}^{2}$, which often results in negative values for the dominance effects. Any sample error in the sire variance component is multiplied times 4 , in order to determine the additive variance. In case of laying workers this factor is 1 , which should reduce the error to a minimum, though oniy $\mathrm{h}^{2}{ }_{\text {ils }}$ can be determined. The rearing of the eggs to pupation in special breeder colonies (RoblerTs, 1961) may reduce environmental effects, and therefore result in larger estimates of the genetic determination of a certain character. In addition all relationships within progenies of laying workers are concise. There is no problem concerning multiple mating of the queen. Effects of an unequal or unhomogenous distribution of semen in the queen's spermatheca have to be estimated in the classical methods by average values for relationships, obtained from experiments with genetic markers (Page \& MetCalf, 1982 ; Moritz, 1983).

Another advantage of laying capensis workers is given in selection programs. In one selective step only, the selection aim can be reached (BRANDES, 
1984). As recombination during meiosis only seems to play a minor role in the parthenogenetic mechanism of laying capensis workers (VERMA and RuTTNER, 1983), the produced offspring almost can be treated as a genetical clone. Therefore, once a certain trait is selected, it can be maintained by laying workers easily.

In spite of these advantages one has to keep in mind that it is not possible to differentiate between additive and dominance effects when using laying $\mathrm{ca}$ pensis workers. Only the heritability in broader sense can be estimated. Especially in applied selection projects this is a disadvantage as one usually selects at the level of colonies and not on individual workers. Only $\mathrm{h}^{2}{ }_{\text {ins }}$ will be an accurate estimator to predict the response to selection. Hence to date $A . m$. capensis will mainly be an important tool in behavioural and experimental genetics. Further work will be necessary to develop applications for practical bee breeding.

Received for publication in July 1984.

Accepted for publication in October 1984.

\section{ACKNOWLEDGEMENTS}

We wish to thank Mrs. M. KüHNERT for carrying out the instrumental inseminations. Financial support was given by the Deutsche Forschungsgemeinschaft. Grant No. Mo 373/1-1.

\section{RÉSUMÉ}

ESTIMATION DES HERITABILITÉS DES CARACTĖRES D'OUVRIERES : NOUVELLE APPROCHE UTILISANT LES OUVRIERES PONDEUSES

DE L'ABEILLE DU CAP (APIS MELLIFICA CAPENSIS ESCH.)

Les ouvrières pondeuses de l'abeille du Cap (Apis mellifica capensis Esch.) nous ont donné la possibilité d'établir les régressions parents-descendants pour évaluer l'héritabilité des caractères des ouvrières. Dans le travail présent, on a comparé cette méthode avec l'analyse classique des fratries (Fig. 1).

On a déterminé chez les ouvrières d'A.m. capensis les héritabilités de 8 caractères morphologiques de l'aile antérieure droite (Fig. 2). Les principaux paramètres de génétique quantitative, qui résultent de l'analyse des fratries, sont résumés dans le tableau 1. Les valeurs négatives de l'estimation pour la variance de dominance $\left(\mathrm{S}_{\mathrm{r}}^{2}\right)$, ainsi que les valeurs $>1$ pour l'héritabilité, sont dues à la taille trop petite de l'échantillon. Le tableau 2 montre que les valeurs d'évaluation fournies par la méthode de régression correspondent bien aux valeurs obtenues par l'analyse des fratries $\left(r_{\mathrm{s}}=0,96\right)$. Les estimations de $\mathrm{h}^{2}$ généralement inférieures lors de l'analyse parents-descendants peuvent être dues en partie à l'estimation plus précise, mais en partie aussi aux effets saisonniers. Dans l'analyse des fratries, tous les insectes étudiés ont éclos simultanément, tandis que dans la méthode de régression les parents n'éclosent pas en même temps que leurs descendants. 
L'avantage des ouvrières pondeuses pour l'estimation de l'héritabilité chez l'abeille réside dans la haute précision de l'estimation. Pour les caractères avec un fort effet de dominance, il faut néanmoins tenir compte du fait que, dans la méthode de régression, l'héritabilité au sens propre peut être fortement surestimée. Les ouvrières pondeuses d'A.m. capensis semblent être un objet idéal pour sélectionner des paramètres particuliers chez des ouvrières.

\title{
ZUSAMMENFASSUNG
}

\author{
SCHATZUNG DER HERITABILITATT VON ARBEITERINNENMERKMALEN : \\ EINE NEUE METHODE MIT HILFE LEGENDER ARBEITERINNEN DER KAPHONIGBIENE \\ (APIS MELLIFERA CAPENSIS ESCH.)
}

Mit Hilfe legender Arbeiterinnen der Kaphonigbiene (Apis mellifera capensis Esch.) ist die Möglichkeit gegeben, auch Eltern-Nachkommen Regressionen zur Schätzung der Heritabilität von Arbeiterinnennerkmalen einzusetzen. In der vorliegenden Arbeit wurde diese Methode mit der klassischen Geschwisteranalyse (Fig. 1) verglichen.

Die Heritabilitäten von acht verschiedenen morphologischen Merkmalen des rechten Vorderflügels (Fig. 2) wurden bei Arbeiterinnen von A.m. capensis bestimmt. Die wesentlichen quantitativ genetischen Parameter, die aus der Geschwisteranalyse resultieren, sind in der Tabelle 1 zusammengefaßt. Die negativen Schätzwerte für die Dominanzvarianz $\left(S^{*}\right)$ ) sowie die Werte größer 1 für die Heritabilität resultieren aus Effekten der zu kleinen Stichprobe. Tabelle 2 zeigt, daß die Schätzwerte aus dem Regressionsverfahren gut mit den Werten aus der Geschwisteranalyse übereinstimmen $\left(r_{s}=96, p=.001\right)$. Die generell kleineren Schätzwerte für h2 bei der Eltern-Nachkommenanalyse können zum einen aus der genaueren Schätzung, zum anderen aber auch aus saisonalen Effekten resultieren. In der Geschwisteranalyse schlüpften alle untersuchten Tiere simultan, während im Regressionsverfahren die Elterngeneration nicht zeitgleich mit ihren Nachkommen schlüpfte.

Der Vorteil legender Arbeiterinnen für Heritabilitätsschätzungen bei der Honigbiene liegt in der hohen Genauigkeit der Schätzung. Bei Merkmalen mit starken Dominanzeffekten muß jedoch berücksichtigt werden, daß im Regressionsverfahren die Heritabilität im engeren Sinne stark überschätzt werden kann. Legende Arbeiterinnen von $A . m$. capensis erscheinen ein ideales Objekt für Selektionsprojekte von Merkmalen individueller Arbeiterinnen.

\section{REFERENCES}

Anderson R.H., 1963, - The laying worker in the Cape honeybee, Apis mellifera capensis. J. Apic. Res., 2, 85-92.

Brandes C., 1984. - Selektion des Lernverhaltens bei der Kaphonigbiene (Apis mellifera capensis Esch.). Apidologie, 15 (3), 273-274.

Brandes C., Moritz R.F.A., 1983. - Evaluation of the heritability of learning behaviour in Apis mellifera L. using the proboscis extension reflex. Verh. Dtsch. Zool. Ges., 1983, 258.

Goncalves L., 1972. - Investigation of the morphological characteristic 'number of hamuli' in Apis mellifera. In : Controlled mating and selection in the honeybee. Ed. Ruttner $\mathrm{H}$. et al. Apimondia, Bukarest, pp. 83-86.

FALCONER D.S., 1981. - Introduction to quantitative genetics, 2nd. - Ed. Longmans, London.

Johansson I., KorkmanN N., 1950. - A study of the variation in production traits of bacon pigs. Acta Agr. Scand., 1, 62-78. 
KRIwzow N.I., 1976. - Erblichkeit und Reproduzierbarkeit ökonomisch wertvoller Me! kmale bei der zentralrussischen Biene. In : Genetik, Selektion und Reproduktion bei der Honigbiene. Ed. Harnaj V.; Bilash G.D., Apimondia, Bukarest, pp. 96-99.

LEE G.L., 1974. - The effect gene dosage on variability in the honeybee. 2. Wing hook number. J. Apic. Res., 13, 257-263.

Malecot G, 1948. - Les mathématiques de l'hérédité. Masson et $\mathrm{C}^{\mathrm{te}}$, Paris.

Moritz R.F.A., 1983 - Homogenous mixing of honeybee semen by centrifugation. J. Apic. Res., 22, 249-255.

Moritz R.F.A., 1984. - Heritabilitätsschätzungen tei der Honigbiene. In : 30. Biometrisches Kolloquium, Int. Biometr. Soc., Dortmund, pp, 76-77.

Oldroyd B., Moran C., 1983. - Heritability of worker characters in the honeybee (Apis mellifera). Alist. J. Biol. Sci., 36, 323-332.

Onions G.W., 1912. - South African «fertile» worker bees. Agric. J. Un. S. Afr., 3, $720-728$.

Page R.E., Metcalf R.A., 1982. -- Multiple mating, sperm utilization, and social evolution. $A m$. Nat., 119, 263-281.

Pirchner F., Ruttner F., Ruttner H., 1962. - Erbliche Unterschiede zwischen Ertragseigenschaften von Bienen XIst. Int. Congr. Entomol., Vienna, Vol. II, 510-516.

Rinderer T.E., 1977 - Measuring the heritability of characters of honeybees. J. Apic. Res., 16, 95-98.

Rinderer T.E., Rothenbuhler W.C., 1969. - Resistance to american foulbrood in honeybees. X. Comparative mortality of queen, worker, and drone larvae. J. Invertebrate Pathol., 13, 81-86.

RoberTs W.C., 1961. - Heterosis in the honeybee as shown by morphological characters in inbred and hybrid bees. Ann. Ent. Soc. Am, 55, 878-882.

RUTTNER F., 1976. - The instrumental insemination of the honey bee queen. Apimondia, Bukarest.

RUtiner F., Hesse B., 1981. - Rassenspezifische Unterschiede in Ovarienentwicklung und Eiablage von weisellosen Arbeiterinnen der Honigbiene Apis mellifera L. Apidologie, 12, 159-183.

Ruttner F., Tassencourt L., Louveaux J., 1978. - Biometrical-Statistical Analysis of the Geographic Variability of Apis mellifera L. Apidologie, 9, 363-381.

SOller M., BAR COHEN R., 1968. - Some observations on the heritability and genetic correlation between honey production and brood area in the honeybee. J. Apic. Res., 6, 37-43.

Verma S., Ruttner F., 1983. - Cytological analysis of the thelytokous parthenogenesis in the cape honeybee (Apis mellitera capensis Esch.). Apidologie, 14, 41-57.

Vesely V., Siller R., 1963. - Die Verwendungsmöglichkeit der quantitativen und Populationsgenetik bei der Rassenzucht von Bienen. XIXth. Int. Beekeep. Congr., Prague, Vol. II, 534-536.

Wright S., 1921. - Systems of matings. Genetics, 6, 111-178. 